\author{
Dušan MALINDŽÁK ${ }^{1}$ \\ Tadeusz OLEJARZ ${ }^{2}$ \\ Andrzej GAZDA ${ }^{3}$
}

\title{
LOGISTICS - SCIENCE OF PRESENT - DAY AND FUTURE
}

\begin{abstract}
Logistics is management of flows and process in chains through time, sequential, space and capacity parameters like capacity usability of equipment, order and amount of produced product, layout of sale and distribution centres, initiate time, processing time and finalizing time of individual process. Criteria of management are capacitive, time, but in global explanation they are economic too. Processes creating chains are purchasing, procurement, storing, transport, production processes, distribution of products, maintenance, etc. managing functions are allocated, layout and set-up, prognosis, aggregation planning, scheduling, dispatching control, monitoring and others. The article describes why logistics has been one of the dynamic factors of the economy and increasing the competitiveness of enterprises in recent decades. It analyzes these factors and shows why orientation towards the systematic building of logistics systems increases their competitiveness. The article also describes the historical development of logistics from the logistics of individual activities to the creation of logistic hierarchical systems and the theoretical basis for the development of logistics as a system science of management. Significantly changes inter-company relationships to different types of SCM, DCM and third logistic party-3PL as a new stage in logistics development. The article also points out that logistics is today an important factor in the development of the economy, an integral part of business management, a solid part of the science of management.
\end{abstract}

Keywords: logistics history, material flows, dynamic factors, SCM, 3-PL.

\footnotetext{
${ }^{1}$ Prof., Dsc, PhD, Eng, Dušan Malindžák, Logistic Institute, FBERG TU Košice, Letná 9, 04000 Košice, Slovakia; e-mail, dusan.malindzak@tuke.sk.

Prof. dr hab. inż. Dušan Malindžák, Instytut Logistyki, FBERG TU Koszyce, Letná 9, 04000 Koszyce, Słowacja; e-mail, dusan.malindzak@tuke.sk.

${ }^{2} \mathrm{PhD}$ Tadeusz Olejarz, Rzeszow University of Technology, Department of Humanities, The Faculty of Management; Powstanców Warszawy Ave. 10, 35-959 Rzeszow, e-mail, olejarz@prz.edu.pl (corresponding author).

Dr Tadeusz Olejarz, Katedra Nauk Humanistycznych, Wydział Zarządzania, Politechnika Rzeszowska, Al. Powstańców Warszawy 10, 35-959 Rzeszów,; e-mail, olejarz@prz.edu.pl (autor korespondencyjny).

${ }^{3}$ Dsc, PhD, Andrzej Gazda, Associate Prof., Department of Management Systems and Logistics, Rzeszow University of Technology, The Faculty of Management; Powstanców Warszawy Ave. 10, 35-959 Rzeszow, e-mail, agazda@ prz.edu.pl.

Dr hab. Andrzej Gazda, prof. PRz, Katedra Systemów Zarządzania i Logistyki, Wydział Zarządzania, Politechnika Rzeszowska, Al. Powstańców Warszawy 10, 35-959 Rzeszów; e-mail, agazda@prz.edu.pl.
} 


\section{INTRODUCTION}

Logistics became at the end of the 20th century one of the dynamics factor of the world economy. In particular, contributed to it, factors such as the globalization of the world market, the development of new methods of informatics, cybernetics and mathematics, but too the development of global information and transport networks and last but not least the fact that the cost of the product is at least $40 \%$ of the cost of the product.

The development of logistics has gone from the management and realization of individual logistics activities such as distribution of goods, supply, storage ${ }^{4}$ to the management of flows in chains of activity, such as in the production company, the basic material chain: supply - storaging - production processes - selling - distribution, to logistics systems represented, for example, micrologistic and macrologistic models ${ }^{5}$.

Inter-company supply chains go from the classic form of the chain: order-productinvoice-payment, to different types of SCM, such as Lean SCM, Agile SCM, DCM, Third logistic party $3 \mathrm{PL}, 4 \mathrm{PL}, 5 \mathrm{PL}^{6}$.

The theoretical basis of logistics is the system approach, the application of the principle of "feed forward" in managing, in particular, time and spatial variables of material, information and financial flows with a view to their overall optimization. Logistics mainly applies tools and methods of planning and scheduling of production, modeling and simulation, heuristics, hierarchical management systems and multi-criteria optimization.

\section{THE LOGISTIC - DYNAMIC FACTORS OF WORLDS’ ECONOMY}

Is the world "logistics" only a new modern world in nowadays science, or is logistics a science, philosophy and industry, which influence the worlds' economy?

Logistics has become in last decades of $20^{\text {th }}$ century and $15-20$ years of $21^{\text {st }}$ century one of the most essential and dynamic factors of worlds' economy. Reasons for that were mostly ${ }^{7}$ :

1. Globalization of world and globalization of world trade.

2. Unbalance between the resources, production and consumption and its allocation in world-wide environment.

${ }^{4}$ D. Malindžák et al, Theory of logistics - definitions, paradigms, principles and structures, Košice 2007; Bigoš a kol., I. Kiss, I.J. Ritók, Materiálové toky a logistika, Prešov 2002.

5 D. Malindžák et al., Theory of logistics...; D. Malindžák, J. Takala, Projecting of logistic systems theory and practice, Košice 2005.

${ }^{6}$ D. Malindžák, J. Mervart, R. Lenort, The logistic principles for fast flexible strategy design of the company in crisis time, ,Managing Global Transitions, International research journal“ 2011, Vol. 9, No. 2, p. 129-149; M. Christopher, Logistics and supply chain management, Strategies for reducting costs and improving services, Finanacial Times Publishing, London 1998; Li X., C. Chung, T.J., Golldsby, C.W. Holsapple, A Unified Model of Supply Chain Agility, the WorkDesign Perspective, "The International Journal of Logistics Management" 2008, Vol. 19, No. 3, p. 408-435; M. Christopher, R., Lowson, H. Peck, Creating Agile Supply Chains in the Fashion Industry, "International Journal of Retail \& Distribution Management" 2004, Vol. 32, No. 8, p. 367-376.

7 D. Malindžák et al., Theory of logistics...; J.C. Johnson, D.F. Wood, Contemporary Logistics, sixth edition, Prentice Hall, Upper Saddle River, N.J. 1996; D. Malindžák, J. Takala, Projecting of logistic systems - theory and practice, Košice 2005. 
3. Development of new management technologies (in mathematics, cybernetics and informatics).

4. Factor of costs and prices reduction. Global competitiveness - period of logistics.

Ad 1)

With the world's globalization and in Europe with the end of socialism, a new market was opened. An environment for movement of investments, materials, products, energy, information and human resources was liberalized. The flow volumes of above-mentioned substances are growing. Build-up of new transportation systems in roads, railways (for example. Europe TINA a TEN) and aerial navigation have positively influence this growth. Creation of world-wide information highways and networks with high speed and volume of transport are revolutionary change also in area of flow management of products, information and finance, which mean of logistic systems. Electronic commerce (order, appraisal of orders, automated payments, electronic signature etc.) increase the efficiency and productivity and support management of business activities - commercial logistics.

Companies realizing the competitive opportunities are creating chains and networks of companies, starting from the raw material mining, processing into polymers and products, delivery to customers, product services, recycling of its wrappings, waste and products itself. Due to these they are creating logistic networks and macro-logistics is developed ${ }^{8}$.

\section{Ad 2)}

Flow as moving substance changing its parameters in time and place, is created as a difference of potentials. We can explain it analogically on an example of electric field. Electric current results from the interconnection of higher potential (+) with lower potential. Logistics creates conditions for flow establishment, manages them and ensures them?

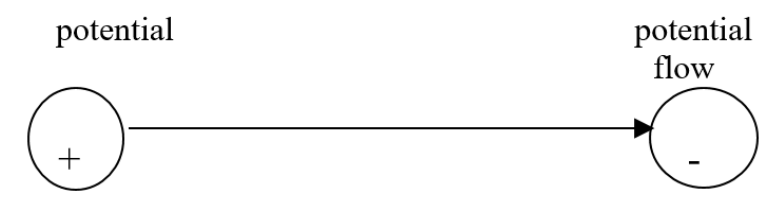

Figure 1. Flow as the results of potential distinction

Source: own.

There is a main difference between potentials in the world:

Raw resources $\rightarrow$ production $\rightarrow$ consumption.

These flows are of vital concern for world operation and liberalization of worlds' economy represented by market economy supports native balancing of these potentials.

${ }^{8}$ D. Malindžák, J. Takala, Projecting of logistic systems - theory and practice, Košice 2005;

M. Straka, Logistics of distribution, How effectively to put product into the market, Bratislava 2013.

${ }^{9}$ D. Malindžák et al., Theory of logistics... 

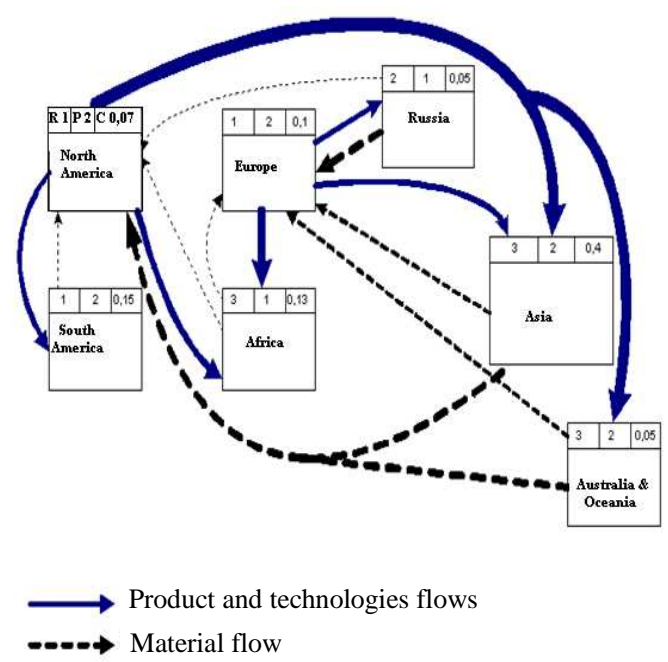

Figure 2. Main material flows of the world

Source: own.

From worlds' statistics it is obvious that if from the global point of view we compare these three potentials resources/R/ - production/P/ - consumption/C/, then these material flows are established by following factors (Figure 2$)^{10}$ :

- Europe and North America draw on roughly half of the raw materials they need for their industry production. That is the reason they need to import the materials.

- Russia and SNŠ countries are dealing with the opposite situation. They draw on almost twice that much of raw materials then they are able to use in their industry production. Asia, Australia and Oceania upraise also almost one third more then they use.

- On the other hand, Europe and North America and their industry produce much more products and technologies then their market can consume. That is the reason they need to export their products mostly to Asia, Africa, SNŠ, South America etc. On Fig. 2. we can see the main material flows. Above each of them, there is a triplet $\mathrm{R} / \mathrm{P} / \mathrm{C}$

$\mathrm{R} / \mathrm{P}$ - proportion of upraise and consumption of raw materials

C - share of world's consumption rising from proportion of population to worlds' population. Together with material flow, there are parallel and inverse flows of information and finance are created.

Unbalance among resources - production - consumption is mostly caused by historical development of economy stage, territorial geology, development of population and living standard. Balancing of these potentials and existence of flows are long-term situation needed to be solved for several decades to come. That is the main reason why logistics plays such an important role in costs and competitiveness.

${ }^{10}$ D. Malindžák, J. Takala, Projecting of logistic systems... 
Ad 3)

Also development of managerial methods contributed to the development of logistics management of distributed companies' productivity, methods of outsourcing, risk management, concentration of capital into big corporations, etc. development of distributed management methods, modelling and simulation, multi-criteria optimizing and its usability within world information networks gives us tools for dealing with the flows within the world-wide environment.

Ad 4)

World-wide market and competitiveness, tendency of producers to muddle through the markets are forcing the producers to cut and reduce their costs. Automation and informatization have increased the productivity of production systems. Times when automation and informatization were leading the dynamic of worlds' economy are over. They are considered to be prevalence in nowadays production systems. It is difficult to picture a successful production without them. The reduction of costs is that's why in the area of connected operations, supporting processes and in its management - in logistics. In compare to automation and informatization of technological processes, allocation of logistics is less expensive and more effective. Mostly it doesn't require high investment but only a good idea, organization and cooperation.

If we take a look at the $20^{\text {th }}$ century, economical dynamic was always influenced by different factors ${ }^{11}$.

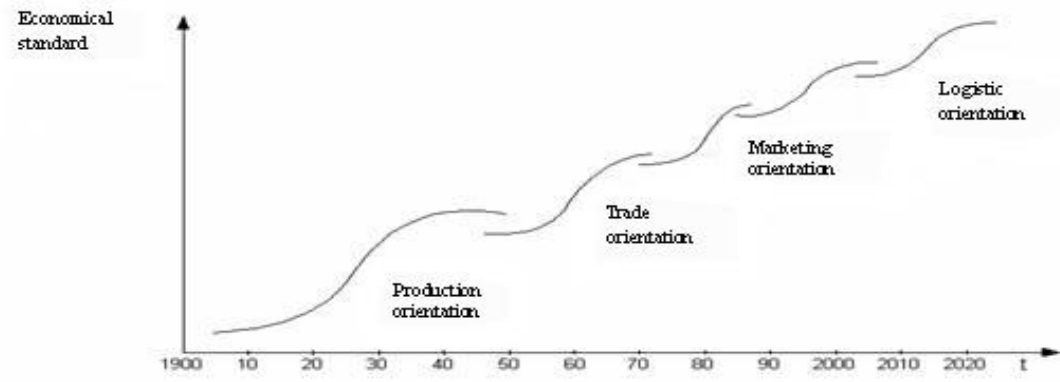

Figure 3. Factors influencing the economy of $20^{\text {th }}$ century

Source: own.

- $\underline{50 \mathrm{~s}-60 \mathrm{~s}}$ of $20^{\text {th }}$ century is also called production oriented economy, which focused on maximizing of production. Main issue was to produce as much as possible. Successful companies were those which could produce the most possible amount.

- $50 \mathrm{~s}-70 \mathrm{~s}$ were mostly oriented on sale - maximizing of sale. Production has exceeded the demand; old markets were totally covered by products. Successful companies were those which could sell as much as possible.

${ }^{11}$ Ibidem. 
- $70 \mathrm{~s}-90 \mathrm{~s}$ are known for their marketing orientation. The aim was to maximize the area of trade. Customers started to be more essential, battles for new markets was common. Research and companies are more interested in marketing strategies. More and more companies base on long-term contracts, strategic customers and trades.

- Last years of $20^{\text {th }}$ century - logistic oriented economy focused on maximal satisfaction of customers. The whole chain of company's activities is oriented on global costs reduction and on final customer.

Global optimizing in the whole chain is replacing the local optimizing of activities; internal management is concentrated on coordination and systematic approach. Quality is becoming more essential together with environmental issues.

The logistic became in last 30th years one of the dominant factor of the world economy and competitions of companies. The development of its theory supported the applications of the practise. This paper is small contribution for logistic theory.

\section{THE LOGISTIC DEVELOPMENT}

Logistics has gone through the following phases since it began to apply in the economy ${ }^{12}$ :

1) Sixty years ago, when logistics development in the US was associated with optimizing the distribution of production, then the relationship between buyers and the market changed, and a marketing philosophy was created. Supply services have been instrumental in market strategy.

2) The second phase is associated with the entry of Japan into the world economy stage, particularly in the field of automation. The European and American response has been reflected in the increased quality of technology in the preparation of orders. Requirements for integration of planning and management of production and distribution have arisen.

3) The third phase, present, is influenced by the JIT philosophy with extensive use of information technology and production optimization.

4) The fourth phase, which is expected to further develop logistics, is to build global logistics systems, including managing logistics chains, maximizing supply potential, production preparation, production, distribution with the goal of creating electronically integrated logistics systems. Moving understanding of logistics from corporate to strategic inter-company logistics/SCM/.

It can be said that the logistics of the 20th century is a discipline of science, management philosophy, a significant area of economics and business, an integral part of almost every process.

Without respecting this we lose the system approach. To apply, the system approach means to create the chain at least from three elements-triad (Figure 2): input element (activity), dominated- managed activity and output activity.

\footnotetext{
${ }^{12}$ M. Christopher, R. Lowson, H. Peck, Creating Agile Supply..., p. 367-376.
} 


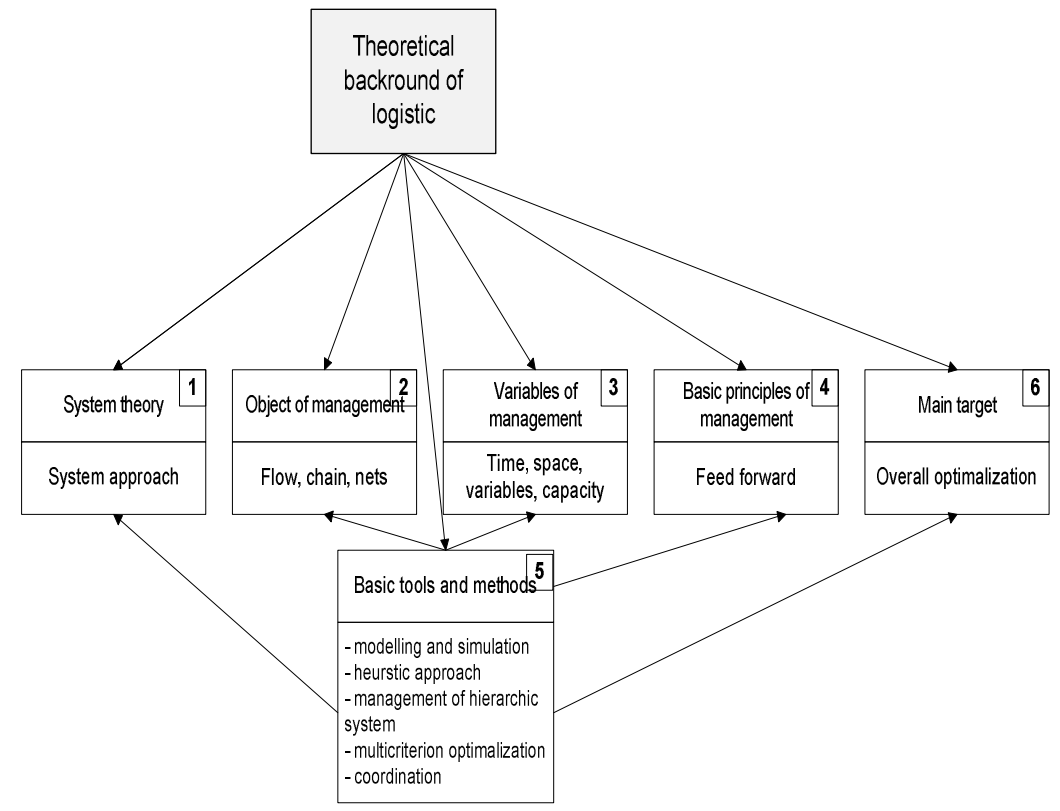

Figure 4. Six main stones of logistic theory

Source: own.

\section{THE LOGISTIC AND SCM RELATION}

In recent years, there is often discussion about the relationship between logistics and SCM. There are four basic views on this relationship:

1. Tradicionalist-logistics is understood to be a wider scope than SCM.SCM is understood to be part of the enterprise's macrologistics as one of the possibilities of inter-company relations.

2. Unionist-where SCM is a wider scope than logistics, because intra-company logistics processes can be considered as strings behind the SCM.

3. Changing-transformational, it is based on the fact that logistics is a historical concept and SCM is a new modern view of the same space.

4. Priencing-overlapping -SCM is understood as part of enterprise logistics and vice versa logistics is just one of the supply system channels-SCM

\subsection{Supply chain}

If the company does not have orders for several weeks in advance, one of the options for this situation long-term solution is to chain/link enterprises and to create a supply chain $^{13}$.

\footnotetext{
${ }^{13}$ I. Gros, S. Grosová, Logistika a marketing v dodavatelských řetězcích, „Logistika“ 2004, nr 7-8,
} p. 48-49; D. Malindžák, J. Mervart, R. Lenort, The logistic principles..., p. 129-149. 


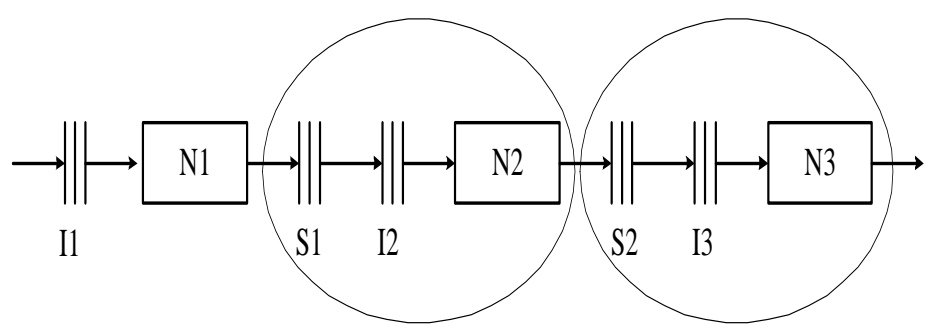

I1, I2, I3 - the entry warehouses of N1, N2, N3 enterprises

$\mathrm{S} 1, \mathrm{~S} 2, \mathrm{~S} 3$ - the exit warehouses of N1, N2, N3 enterprises

Figure 5. Supply chain application

Source: own.

For example: enterprise N1 receives or gains the manufacturing plan forecast of enterprise $\mathrm{N} 2$ and $\mathrm{N} 2$ enterprise will specify, how big the stock produced by N1 should be e.g. in $\mathrm{T}_{1}, \mathrm{~T}_{2} \ldots \ldots \mathrm{T}_{\mathrm{N}}$ period in the exit warehouse of $\mathrm{N} 1$ company. The same will apply for $\mathrm{N} 3$ enterprise, which will specify the volume of inventory for the same $T_{1}, T_{2} \ldots \ldots T_{N}$ period as in $\mathrm{N}_{2}$ enterprise etc. (see the figure 3). This will enable to manage these enterprises in the long run and to increase the uniformity of production, to create optimum production batches, and to generate internal orders by accumulation of a larger number of orders for a longer period of time. This all, however, is just a forecast. As a part of this forecast business is carried out on the basis of particular orders. The supply chain is mostly initiated by the companies with the strongest position in the chain or based on the agreement of all companies becoming a part of this chain.

\subsubsection{Lean supply chain}

Lean thinking was conceptualized to apply to all activities in the firm and across the companies in the supply chain. Lean thinking in supply chain is the use of lean principles to align activities across corporate functions within the firm and to manage business relationships with customers and suppliers ${ }^{14}$.

What makes a supply chain lean? To begin with, a lean supply chain seeks to reduce wastes found anywhere in the supply network, standardize processes across traditional, vertical organizations, and optimize core resources. Lean supply chains seek to create customer-winning value at the lowest cost through the real-time synchronization of product/service needs with the optimum supplier. Achieving such objectives requires supply chain to be responsive (capable of meeting changes in customer needs for requirements such as alternative delivery quantities and transport modes) as well as flexible (adapting assets, pursuing outsourcing, and deploying dynamic pricing and promotions). Finally, lean supply chains are dedicated to the continuous improvement of people and processes throughout the extended supply chain. How do companies develop the lean supply chain capabilities that will lead to the kind of superior supply chain performance demonstrated

\footnotetext{
${ }^{14}$ I. Gros, S. Grosová, Logistika a marketing..., s. 48-49; D. Malindžák, J. Mervart, R. Lenort, The logistic principles...,p. 129-149.
} 
by the top adopters and the industry leaders? Abbott et al. identified six attributes that companies should strive to develop:

1. Demand management capability - an underlying tenet of the lean philosophy is that product should be "pulled" by actual customer demand rather than "pushed" into the market;

2. Waste and cost reduction - in the broadest sense, waste can be time, inventory, process redundancy, or even digital waste;

3. Process and product standardization - it's important to develop standardization across both processes and products;

4. Industry standards adoption - standardization also needs to extend beyond a company's particular supply chain to the industry overall;

5. Cultural change competency - there is one recurring obstacle to successfully applying lean supply chain concepts, i.e. resistance from the people who will be asked to embrace and implement the chase;

6. Cross-enterprise collaboration - through collaborative practices and processes, supply chain partners must work to maximize the value stream to the customer.

\subsubsection{Agile supply chain}

Agility is another concept often cited together with lean. Lean concepts work well where demand is relatively stable and hence is volatile and where variety is low. Conversely, in those contests where demand is volatile and the customer requirement for variety is high, a much higher level of agility is required ${ }^{15}$.

Agility, as a business concept, was coined in the manufacturing context - particularly in relation to flexible manufacturing systems. This concept was refined by Naylor et al. with a major focus on agility in supply chains ${ }^{16}$. By synthesizing representative agility definitions from several disciplines, Li et al. advance a unifying general-purpose definition of agility as follows ${ }^{17}$ : "Agility is the result of integrating an alertness to changes (opportunities/challenges) - both internal and environmental - with a capability to use resources in responding (proactively/reactively) to such changes, all in a timely, and flexible manner."

Harrison et al. and Christopher et al. identify characteristics that a supply chain must have in order to be agile ${ }^{18}$ :

- Market sensitive - closely connected to end-user trends,

- Virtual - relies on shared information across all supply chain partners,

- Network-based - gains flexibility by using the strengths of specialist players,

- Process aligned (process integration) - it has a high degree of process interconnectivity between the network members.

15 D. Malindžák, J. Mervart, R. Lenort, The logistic principles..., p. 129-149; M. Christopher, Logistics and supply chain management, Strategies for reducting costs and improving services, London 1998.

16 J.B, Naylor, M.M Naim., Berry D., Leagility: Interfacing the Lean and Agile Manufacturing Paradigm in the Total Supply Chain, "International Journal of Production Economics" 1999, Vol. 62, p. 107-118.

${ }^{17}$ Li X., C. Chung, T.J. Golldsby, C.W. Holsapple, A Unified Model..., p. 408-435.

18 M. Christopher, R. Lowson, H. Peck, Creating Agile Supply..., p. 367-376; A. Harrison, M. Christopher, R. Van Hoek, Creating the Agile Supply Chain Working paper, School of Management, Cranfield, 1999. 


\subsubsection{Leagile supply chain}

Naylor et al. coined the term "leagile" to refer to hybrids of the lean and agile approaches ${ }^{19}$. Here are three proven ways in which the concepts have been brought together to provide available and affordable products for the end customer:

- The Pareto curve approach - the Pareto (80/20) rule, recognizing that $80 \%$ of a company's revenue is generated from $20 \%$ of the products. It is suggested that the fastmoving products that make up the dominant $20 \%$ of the product line can be produced in a lean, make-to-stock manner given that demand is relatively stable for these items and that efficient replenishment is the appropriate objective. Meanwhile, the remaining $80 \%$ should be produced in an agile, less anticipatory manner, perhaps even employing make-to-order production to generate supply for only those items ordered when they are ordered ${ }^{20}$.

- The de-coupling point approach - here is idea to hold strategic inventory in some generic or modular form and only complete the final assembly or configuration when the precise customer requirement is known. Companies may utilise lean methods up to the de-coupling point and agile methods beyond it.

- Separation of "base" and "surge" demands - base demand can be forecast on the basis of past history whereby surge demand typically cannot. Base demand can be met through classic lean procedures to achieve economies of scale whereas surge demand is provided for through more flexible, and probably higher cost, processes.

\subsubsection{Demand chain}

This philosophy has recently led mainly to bigger pressure from chain dominant enterprises that specify, for their sub-suppliers, the volume of products and the period $\left(T_{1}, T_{2}\right.$ ....... $\mathrm{T}_{\mathrm{N}}$ ), in which the given volume should be either in a warehouse close to their premises or directly in entry i.e. disposition warehouses. The above-mentioned goods will be owned by the supplier up to the moment of their release from the disposition warehouse. Once released the following will take place: deal - order - invoice - payment to the sub-supplier. We would like to stress out once more that the goods in disposition warehouses are owned by sub-suppliers, which forces each enterprise in the chain to make its sub-suppliers create I0, I1, I2 dispatch warehouses in its premises (see the figure 4). Each company in the chain has to require this from its sub-suppliers. Otherwise it will pay for the given warehouses (product cost, storage cost included) at the entry and at the exit of the enterprise itself, thus having a disadvantage compared to the rest of the demand chain ${ }^{21} \mathrm{DCH}$ members.

\footnotetext{
${ }^{19}$ J.B. Naylor, M.M. Naim., D. Berry, Leagility: Interfacing the Lean..., p. 107-118.

${ }^{20}$ M. Christopher, R. Lowson, H. Peck, Creating Agile Supply..., p. 367-376.

${ }^{21}$ I. Gros, S. Grosová, Logistika a marketing...; D. Malindžák, J. Mervart, R. Lenort, The logistic principles..., p. 129-149.
} 


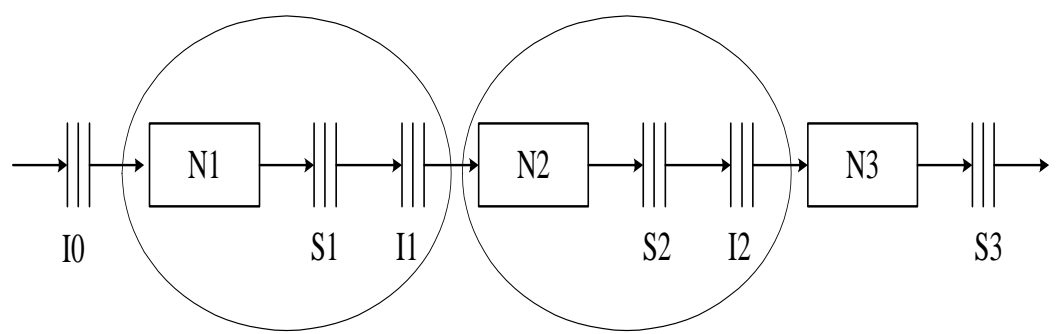

I0, I1, I2 - the disposition warehouses of N1, N2, N3 enterprises $\mathrm{S} 1, \mathrm{~S} 2, \mathrm{~S} 3$ - the exit warehouses of N1, N2, N3 enterprises

Figure 6. The principle of $\mathrm{I}_{0}, \mathrm{I}_{1}$ demand chain application

Source: own.

Once the dominant or final company of the chain defines its requirements (demand) related to the volume of products available in sub-supplier's disposition warehouses for several scheduling periods in advance - as a forecast of its most probable needs, this logistic strategy will enable all the members of this demand chain to achieve benefits in the following aspects:

- optimum production batches, which can be formed when accumulating forecasted sub-suppliers' requirements for a longer period of time;

- they can produce temporarily to stock, when the given product is to be delivered in some of the coming scheduling periods;

- if the manufacturing capacity is not used in a sufficient manner, production can be carried out in advance;

- thus it is more stable and uniform and results in better manufacturing productivity;

It is important to maintain discipline in a demand chain, which can be embodied in bilateral or multilateral contracts for the entire chain.

The question is how much of its capacity the enterprise will devote to SCH and DSCH.

The relations and obligations within $\mathrm{SCH}$ and $\mathrm{DCH}$ are beneficial as long as the enterprises in the chain function and fulfill agreements. This strategy is suitable when cooperating mainly with strategic partners.

If, however, any of these strategic partners fall out of the chain for some reason, all its sub-suppliers i.e. previous members of the chain will face the consequences of their membership in the given chain, i.e. all of them will have insufficient coverage of their production capacities.

Therefore the enterprise should consider the extent, into which it will devote its capacities to $\mathrm{SCH}$ and $\mathrm{DCH}$ in order to leave certain capacity for its new potential customers. The optimum volume of production capacity dedicated to $\mathrm{SCH}$ and $\mathrm{DCH}$ seems to be max. $60-70 \%$.

\subsection{Third party logistic strategy}

Not all entities involved in the production, transport and other activities must be part of the SCM. The cooperating entities with the SCM are called "Third Party". Under the cooperation framework, the five levels are defined: 
1PL-all logistics activities-transport, storage, distribution, information services, chain management are provided by single members of the chain themselves

2PL-non-SCM entities that provide transport or storage services to individual members of SCM or the entire chain

3PL-non-SCM entities that provide complex logistic services for individual members of the SCM or for the whole chain, such as contract, legal, shipping, warehousing, distribution

4PL-non-SCM entities that provide for SCM IKT services for all members of the SCM, planning, managing all SCM chain functions

5PL- non-SCM entities that design, create and run a new SCM

\section{SUMMARY}

The logistic became in last 30th years one of the dominant factor of the world economy and competitions of companies. The development of its theory supported the applications to the practise.

Globalization of world trade, unbalance between the resources, production and consumption and its allocation in world-wide environment, development of new management technologies and cybernetics and informatics methods and factor of logistics costs and prices reduction create conditions for rapid development of logistics

The article also points out that logistics is today an important factor in the development of the economy, an integral part of business management, a solid part of the science of management.

This paper is small contribution for logistic theory and its history.

\section{REFERENCES}

1. Bigoš a kol., I. Kiss, Ritók, J., Materiálové toky a logistika. Prešov, Vydavatel'stvo M. Vaška, 2002.

2. Christopher M., Lowson R., Peck H., Creating Agile Supply Chains in the Fashion Industry, "International Journal of Retail \& Distribution Management" 2004, Vol. 32, No. 8.

3. Christopher M., Logistics and supply chain management: Strategies for reducting costs and improving services, Finanacial Times Publishing, London 1998.

4. Gros I., Grosová S., Logistika a marketing v dodavatelských řetězcích, „Logistika“ 2004, No. 7-8, Economia Praha.

5. Harrison A., Christopher M., Van Hoek R., Creating the Agile Supply Chain Working paper, School of Management, Cranfield University, Cranfield 1999.

6. Johnson J.C., Wood D.F., Contemporary Logistics, sixth edition, Prentice Hall, Upper Saddle River, N.J. 1996.

7. Li X., Chung C., Golldsby T.J., Holsapple C.W., A Unified Model of Supply Chain Agility: the Work-Design Perspective, "The International Journal of Logistics Management" 2008, Vol. 19, No. 3 .

8. Malindžák D. et al., Theory of logistics - definitions, paradigms, principles and structures, Karnat, Košice 2007. 
9. Malindžák D., Mervart J., Lenort R., The logistic principles for fast flexible strategy design of the company in crisis time, ,Managing Global Transitions: International research journal“ 2011, Vol. 9, No. 2.

10. Malindžák D., Takala J., Projecting of logistic systems - theory and practice, Expres Publicit s.r.o., Košice 2005.

11. Naylor J.B., Naim M.M., Berry D., Leagility: Interfacing the Lean and Agile Manufacturing Paradigm in the Total Supply Chain, "International Journal of Production Economics" 1999, Vol. 62.

12. Straka M., Logistics of distribution, How effectively to put product into the market, EPOS, Bratislava 2013

13. Viestová K., Štofilová J., Oreský M., Škapa R., Lexicon of logistics, first edition, Ekonóm Bratislava 2005

\section{LOGISTYKA - WSPÓŁCZESNOŚĆ I PRZYSZŁOŚĆ}

Logistyka to zarządzanie przepływami i procesami w łańcuchach logistycznych z uwzględnieniem czasu, sekwencji, przestrzeni i przepustowości, z wykorzystaniem takich parametrów jak zdolność produkcyjna urządzeń, zamówienia i ilość wytworzonych produktów, rozmieszczenie centrów sprzedaży i dystrybucji, czas rozpoczęcia, czas operacji i czas zakończenia poszczególnych procesów. Kryteriami zarządzania jest przepustowość, czas, ale w globalnych warunkach są także uwzględniane kryteria ekonomiczne. Procesy tworzenia łańcuchów obejmują zakupy, zaopatrzenie, magazynowanie, transport, procesy produkcyjne, dystrybucję produktów, utrzymanie zdolności produkcyjnej itp. realizowane przez takie funkcje, jak rozmieszczenie urządzeń, konfiguracja, prognozy, planowanie i zagregowane planowanie, kontrola wysyłek, monitorowanie i inne. Artykuł przedstawia odpowiedź na pytanie, dlaczego logistyka stała się jednym z dynamicznych czynników rozwoju gospodarki i zwiększenia konkurencyjności przedsiębiorstw w ostatnich dziesięcioleciach. Analizuje te czynniki i pokazuje, dlaczego orientacja na systematyczne budowanie systemów logistycznych zwiększa ich konkurencyjność. Artykuł opisuje również historyczny rozwój logistyki od logistyki poszczególnych działań do tworzenia logistycznych systemów hierarchicznych i teoretycznych podstaw rozwoju logistyki jako systemowej nauki zarządzania. Znacząco zmienia relacje między przedsiębiorstwami, wykorzystując takie systemy, jak SCM, DCM i logistyka trzeciej strony - 3PL stanowiące nowy etap rozwoju logistyki. Ponadto artykuł wskazuje też, że logistyka jest dziś ważnym czynnikiem rozwoju gospodarki, integralną częścią zarządzania przedsiębiorstwem, istotną częścią nauki o zarządzaniu.

Słowa kluczowe: historia logistyki, przepływy materiałowe, czynniki dynamiczne, SCM, 3PL.

DOI: $10.7862 /$ rz.2018.mmr.15

Tekst złożono $w$ redakcji: luty $2018 r$.

Przyjęto do druku: czerwiec $2018 \mathrm{r}$. 
